\title{
The bivalve loop: Intra-specific facilitation in burrowing cockles through habitat modification ${ }^{\text {t2 }}$
}

\author{
Serena Donadi a,*,1, Els M. van der Zee ${ }^{\mathrm{b}, \mathrm{c}}$, Tjisse van der Heide ${ }^{\mathrm{d}}$, Ellen J. Weerman ${ }^{\mathrm{d}}$, Theunis Piersma ${ }^{\mathrm{b}, \mathrm{c}}$, \\ Johan van de Koppel ${ }^{\text {d,e }}$, Han Olff ${ }^{\mathrm{d}}$, Marc Bartelds ${ }^{\mathrm{a}}$, Imke van Gerwen ${ }^{\mathrm{a}}$, Britas Klemens Eriksson ${ }^{\mathrm{a}}$ \\ ${ }^{a}$ Department of Marine Benthic Ecology and Evolution, Centre for Ecological and Evolutionary Studies (CEES), University of Groningen, P.O. Box 11103, 9700 CC Groningen, The Netherlands \\ ${ }^{b}$ Animal Ecology Group, Centre for Ecological and Evolutionary Studies (CEES), University of Groningen, P.O. Box 11103, 9700 CC Groningen, The Netherlands \\ c Department of Marine Ecology, Royal Netherlands Institute for Sea Research (NIOZ), P.O. Box 59, 1790 AB Den Burg, Texel, The Netherlands \\ ${ }^{d}$ Community and Conservation Ecology Group, Centre for Ecological and Evolutionary Studies (CEES), University of Groningen, P.O. Box 11103, 9700 CC Groningen, The Netherlands \\ e Spatial Ecology Department, Royal Netherlands Institute for Sea Research (NIOZ), P.O. Box 140, 4400 AC Yerseke, The Netherlands
}

\section{A R T I C L E I N F O}

Article history:

Received 10 April 2014

Received in revised form 5 July 2014

Accepted 27 July 2014

Available online $\mathrm{xxxx}$

\section{Keywords:}

Arenicola marina

Cerastoderma edule

Ecosystem engineer

Facilitation

Mytilus edulis

Wadden Sea

\begin{abstract}
A B S T R A C T
Human exploitation of bivalve populations has changed intertidal landscapes worldwide. Many bivalves are ecosystem engineers that modify the physical environment, affecting the conditions for their survival. Here we argue that lack of recovery of overexploited intertidal bivalve beds may be partly caused by the loss of important biological feedbacks from depleted populations. In a large-scale experiment we investigated engineering effects of cockles (Cerastoderma edule L.) and lugworms (Arenicola marina L.) on juvenile cockles by adding high densities of either species to $5 \times 5 \mathrm{~m}$ plots in areas with different hydrodynamic and sediment conditions in the intertidal flats of the Wadden Sea. We hypothesized that cockles would facilitate the new generations by increasing sediment stability, while lugworms would have negative effects on juvenile cockles through sediment disturbance. We found that in sandy areas with high wave and current energy cockles enhanced sediment accumulation and promoted local densities of young cockles, while lugworms did not have any effect on juvenile cockles. In muddy sites sheltered from the tidal currents by mussel reefs (Mytilus edulis L.), juvenile cockle densities were generally high, demonstrating the general importance of biological engineering for recruitment processes in the intertidal. We suggest that the acknowledgement of positive feedbacks between bivalves and sediment stability is essential to achieve long-term restoration goals in coastal ecosystems.
\end{abstract}

(c) 2014 Elsevier B.V. All rights reserved.

\section{Introduction}

Overfishing and habitat destruction have led to dramatic reductions in bivalve populations worldwide (Airoldi and Beck, 2007; Jackson et al., 2001; Lotze et al., 2006 and references therein; van Gils et al., 2006). The rate of decline has accelerated dramatically within the last two hundred years, bringing several species close to collapse (e.g. Kirby, 2004; Lotze, 2005). Although the results of restoration efforts are encouraging (e.g. Arnold et al., 2005; Marsden and Adkins, 2009; Schulte

\footnotetext{
is Author contribution: BKE, SD, TvdH, EMvdZ, HO, JvdK and TP conceived and designed the experiments. SD, EMvdZ, EJW, TvdH, IvG, MB and BKE performed the experiments. SD and BKE analyzed the data. SD, BKE, JvdK, EMvdZ, EJW, TvdH, HO and TP wrote the manuscript.

* Corresponding author. Tel.: +4915 778711163

E-mail addresses: s.donadi@rug.nl (S. Donadi), els.vanderzee@nioz.nl (E.M. van der Zee), t.vanderheide@science.ru.nl (T. van der Heide), ellenweerman@gmail.com (E.J. Weerman), Theunis.Piersma@nioz.nl (T. Piersma), Johan.van.de.Koppel@nioz.nl (J.van de Koppel), h.olff@rug.nl (H. Olff), marcbartelds@gmail.com (M. Bartelds), I.van.Gerwen@student.rug.nl (I. van Gerwen), b.d.h.k.eriksson@rug.nl (B.K. Eriksson).

1 Present address: Department of Ecology, Environment and Plant Sciences, Frescati backe, Stockholm University, SE-106 91 Stockholm, Sweden.
}

et al., 2009), large-scale restoration of shellfish stocks often remains difficult. Lack of recovery has been attributed to multiple, likely interacting factors such as food web changes (i.e. the arrival of new competitors or predators, Walters and Kitchell, 2001), habitat destruction (e.g. Lenihan and Peterson, 1998; Medina et al., 2007), climate change (e.g. Schückel and Kröncke, 2013), and pollution (Worm and Lotze, 2000). A possibly underestimated cause preventing re-establishment of former abundance levels is the loss of biological feedbacks from pre-existing populations. Many bivalve species act as ecosystem engineers that often modify their environment to their own benefit (Bertness and Leonard, 1997; Jones et al., 1994, 1997). The eradication of natural populations can break such positive feedbacks resulting in degraded habitat conditions that are hard to reverse (Nyström et al., 2012; Thrush et al., 2009).

Positive feedbacks have been suggested to be crucial for the stability and resilience of ecological communities (Gurney and Lawton, 1996; Scheffer and Carpenter, 2003), potentially leading to the occurrence of alternative stable states in ecosystems (May, 1977; Scheffer et al., 2001). In many species, habitat modification may affect the dynamics of future generations ("ecological imprint") by increasing the probability of successful recruitment (Cuddington et al., 2009; Laland et al., 1999). This in turn may drive spatial segregation of species, resulting 
in self-organized spatial heterogeneity (Hui et al., 2004). Hence, positive feedbacks can strongly influence the distribution, persistence and dynamics of natural populations, emphasizing that appreciation of these mechanisms is crucial for conservation and restoration of ecosystem engineers (Boogert et al., 2006; Byers et al., 2006).

In this study, the effects of sediment-stabilizing bivalves (Cerastoderma edule - cockle) and sediment-destabilizing worms (Arenicola marina - lugworm) on juvenile cockles were investigated on the tidal flats of the Dutch Wadden Sea. Cockles live in the upper few $\mathrm{cm}$ of the sediment and can occur in dense assemblages of many thousands $\mathrm{m}^{-2}$ (Jensen, 1992). Although several studies emphasized the bioturbating effects of cockles (Flach, 1996; Neumeier et al., 2006), high densities of cockles can also increase sediment stability through the production of mucus-rich biodeposits and facilitation of sedimentbinding diatom colonies (Ciutat et al., 2007; Donadi et al., 2013b). Sediment stabilization may affect cockle recruitment and post-larval processes (Bouma et al., 2001; Kater et al., 2006; Piersma et al., 2001), for instance by enhancing the ability of juvenile bivalves to anchor themselves to the substrate, thereby buffering negative effects of waves and currents (Armonies, 1996; Armonies and Hellwig-Armonies, 1992). Another common ecosystem engineer occurring in high abundances on tidal flats is the deposit-feeding lugworm A. marina (Flach and Beukema, 1994). Through bioturbation, lugworms increase erosion of fine particles thus decreasing sediment stability (Volkenborn et al., 2007). Moreover, sediment cohesiveness can be further reduced by the removal of diatom mats due to deposit feeding by the worms (Volkenborn et al., 2007). Consequently, lugworms likely decrease larval settlement and/or increase resuspension of macrozoobenthos recruits. Indeed, previous studies attributed observed negative effects of lugworms on juveniles of $C$. edule and several other species to sediment re-working activities and repeated burying by fecal castings (Brey, 1989; Flach, 1992).

Here, we hypothesize that (1) adult cockles can facilitate recruitment of juvenile conspecifics and that (2) lugworms could disrupt these positive feedbacks via habitat-modification. As the intensity of ecosystem engineering by cockles and lugworms likely depends on environmental conditions (Montserrat et al., 2009; Volkenborn et al., 2007), we tested our hypotheses by adding a total of 800.000 cockles and 64.000 lugworms to $5 \times 5 \mathrm{~m}$ plots in habitats with contrasting hydrodynamic and sediment properties caused by the nearby presence or absence of blue mussel (Mytilus edulis) reefs. In addition, to explore the relative importance of ecosystem engineering by cockles and lugworms versus the effects of the local species, half of the plots were defaunated before the additions.

\section{Methods}

\subsection{Experimental treatments}

The study was conducted on the intertidal flats of Schiermonnikoog, in the Dutch Wadden Sea. On these tidal flats, blue mussels form several large ( $>1$ ha) epibenthic reefs, cockles are often found in dense assemblages within the sediment of hundred to thousand individuals $\mathrm{m}^{-2}$ and lugworms occur in populations with relatively stable densities of 20-40 individuals $\mathrm{m}^{-2}$ (Beukema and Devlas, 1979; Jensen, 1992), as confirmed by pilot surveys conducted in 2009 in the study area (pers. obs.).

We used a large-scale experiment to investigate the effects of cockles and lugworms on recruitment success of juvenile cockles, defined here as the result of settlement and survival of 3 to 6 month individuals. In March 2010, a total of ninety-six $5 \times 5 \mathrm{~m}$ plots arranged in a randomized block design were assigned to two muddy sites $\left(53^{\circ} 28^{\prime}\right.$ $\left.8.15^{\prime \prime} \mathrm{N}, 6^{\circ} 13^{\prime} 27.95^{\prime \prime} \mathrm{E} ; 53^{\circ} 28^{\prime} 2.44^{\prime \prime} \mathrm{N}, 6^{\circ} 10^{\prime} 59.83^{\prime \prime} \mathrm{E}\right)$ located 100 and $350 \mathrm{~m}$ coastward of two mussel beds, and two sandy sites $\left(53^{\circ} 28^{\prime}\right.$ $7.42^{\prime \prime} \mathrm{N}, 6^{\circ} 13^{\prime} 55.95^{\prime \prime} \mathrm{E} ; 53^{\circ} 28^{\prime} 7.54^{\prime \prime} \mathrm{N}, 6^{\circ} 11^{\prime} 33.48^{\prime \prime} \mathrm{E}$ ) far from the influence of mussel reefs, at the same tidal elevation, respectively. Previous research highlighted the engineering effects of the same mussel reefs considered in the current study by showing strong spatial gradients of increasing organic matter and silt content, and decreasing pore water redox potential and current velocities in the direction of the reefs (Donadi et al., 2013a; van der Zee et al., 2012). This evidence together with the absence of any macroscopic topographical features in the area assured us that the differences in sediment composition between muddy and sandy sites were due to engineering effects of the mussel beds (e.g. biodeposition, shelter from tidal currents). In each site we set up two blocks of twelve plots with a random full factorial combination of (1) defaunation treatment (two levels) and (2) engineer addition (three levels) (Fig. 1). The defaunation treatment consisted of an anoxia-induced kill off of macrobenthos in half of the plots by covering the sediment with plastic tarps for a period of 28 days (April 2010). After this period, the tarps were removed and the absence of living macrobenthic organisms was confirmed by the collection of sediment cores. Ten days after the removal of the tarps, we performed the engineer addition: one-third of all plots was enriched with high densities of cockles ( 1000 individuals $\mathrm{m}^{-2}$ ), one-third with high densities of lugworms ( 80 individuals $\mathrm{m}^{-2}$ ) and the remaining plots served as a control (no addition). As effects of ecosystem engineers are strongly dependent on the densities and the spatial extent of the engineer populations and considering the highly patchy distribution of cockles on intertidal areas, treatment densities of cockles and lugworms were chosen to mimic maximum adult densities in the study area, as estimated within a $0.5 \times 0.5 \mathrm{~m}$ frame during several pilot surveys conducted between March and October 2009 (pers. obs.). Cockles were collected from a nearby intertidal flat by professional fishermen through hand-raking and were 2 to 4 years old (mean mm length $\pm \mathrm{SE}=32.40 \pm 0.78, \mathrm{n}=$ 15). Lugworms were harvested by a commercial lugworm fishery company (Arenicola BV, Oosterend, The Netherlands) from an intertidal flat in the Western Wadden Sea (mean g. dry weight $\pm \mathrm{SE}=0.97 \pm 0.12$, $\mathrm{n}=20$ ).

Total abundance of engineers was monitored every six months by counting cockles (one replicate per plot) and lugworm fecal casts (three replicates per plot) within a $0.5 \times 0.5 \mathrm{~m}$ frame. Abundances of both cockles and lugworms generally decreased after the additions (also because of a winter freeze between 2010 and 2011) but remained considerably higher in enriched plots compared to the other treatments (Figs. 2 and 3), the only exception being lugworm abundances in September 2011, when there was mostly no difference between cockle- and lugworm-addition plots (Fig. 3).

\subsection{Juvenile cockles and sediment conditions}

Abundance of juvenile cockles (3-12 mm long, 3-6 months-old) was estimated within a $0.5 \times 0.5 \mathrm{~m}$ frame which was randomly placed on each plot in September 2010, March 2011, July 2011 and September 2011. Cockles commonly settle in the Wadden Sea in late spring (MayJune) and in late autumn (October-November, van der Veer et al., 1998; R. Dekker, pers. comm.). At each sampling time, juvenile cockles were counted after sieving the upper sediment layer $(0-3 \mathrm{~cm}$ depth $)$ through a 1-mm mesh. To minimize sampling effects, the sediment was put back in place after sieving and leveled with the surrounding bed level.

To investigate engineering effects of transplanted species on sediment accretion and erosion we estimated bed level height in March 2011 and September 2011 using a Trimble Spectra Precision LL500 Laser Level (Trimble, California, United States of America). At each site, measurements were calibrated against fixed reference metal poles. At each sampling time, five replicates per plot were collected and averaged and the differences between the two dates were used to calculate bed level changes (a proxy for net sediment accumulation or erosion) during the summer, when bioengineering activity of cockle and lugworms is more conspicuous.

To explore effects of cockles and lugworms on sediment properties, sediment samples were collected in September 2010, March 2011 and 


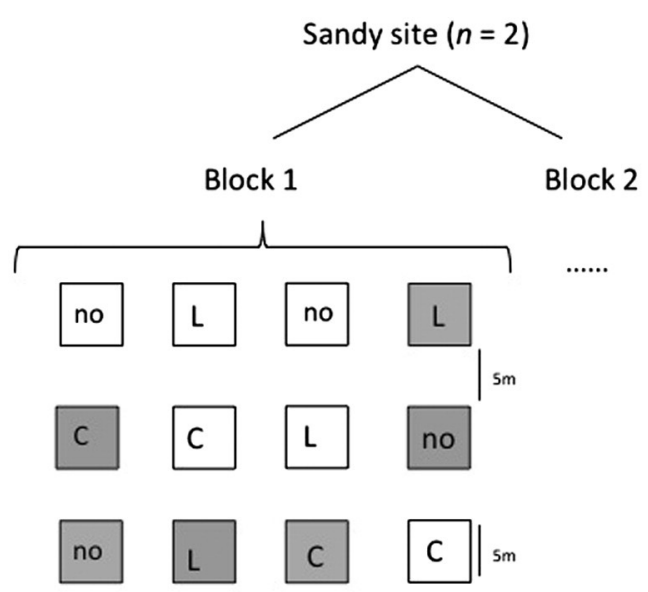

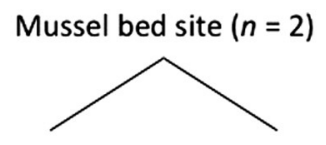

Block 1

Block 2

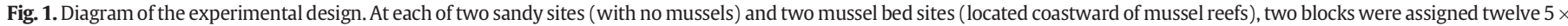

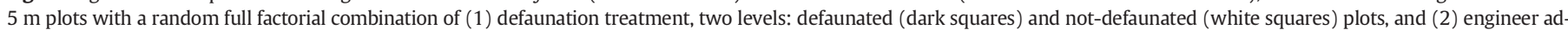
dition, three levels: cockle addition (C), lugworm addition (L), no addition (no).

September 2011 to a depth of $5 \mathrm{~cm}$ through cut disposal syringes (2.4 $\mathrm{cm}$ internal diameter). Organic matter content was estimated from oven-dried $\left(48 \mathrm{~h}, 75^{\circ} \mathrm{C}\right)$ samples as Loss On Ignition (LOI; $4 \mathrm{~h}$, $550{ }^{\circ} \mathrm{C}$ ), and silt content was measured with a Malvern particle size analyzer (Malvern Particle Sizer 2000, United Kingdom) after freezedrying the sediment samples.

\subsection{Hydrodynamic conditions and field surveys}

Differences in hydrodynamic conditions between the experimental sites were assessed in October 2010, April and June 2011 as percentage of weight loss of plaster cylinders. Cylinders $(6.3 \mathrm{~cm}$ long; $2.4 \mathrm{~cm}$ diameter) were molded with model plaster (Knauf Modelgips, Knauf B.V.,

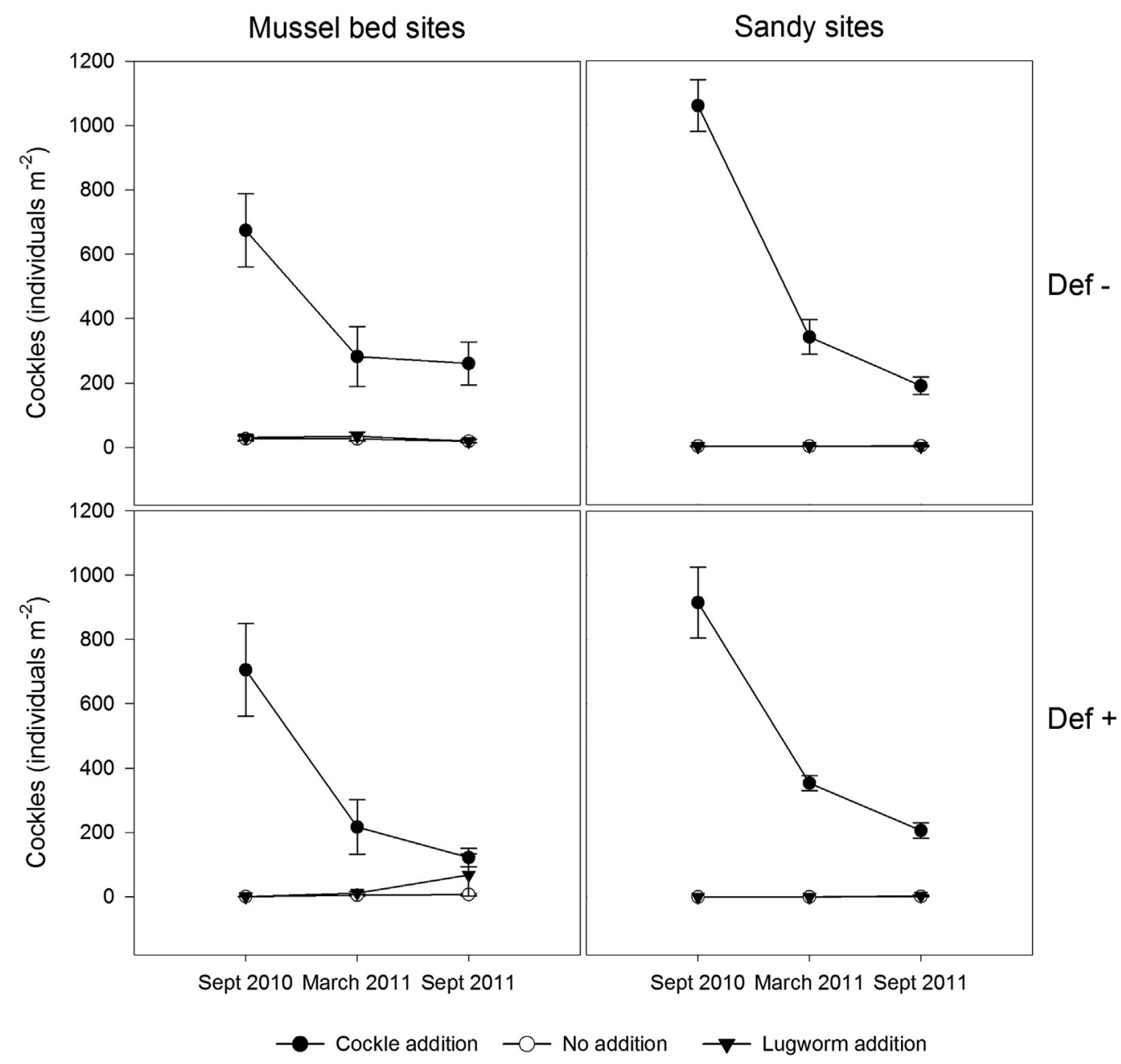

Fig. 2. Total abundances of cockles in the experimental plots over one year. 


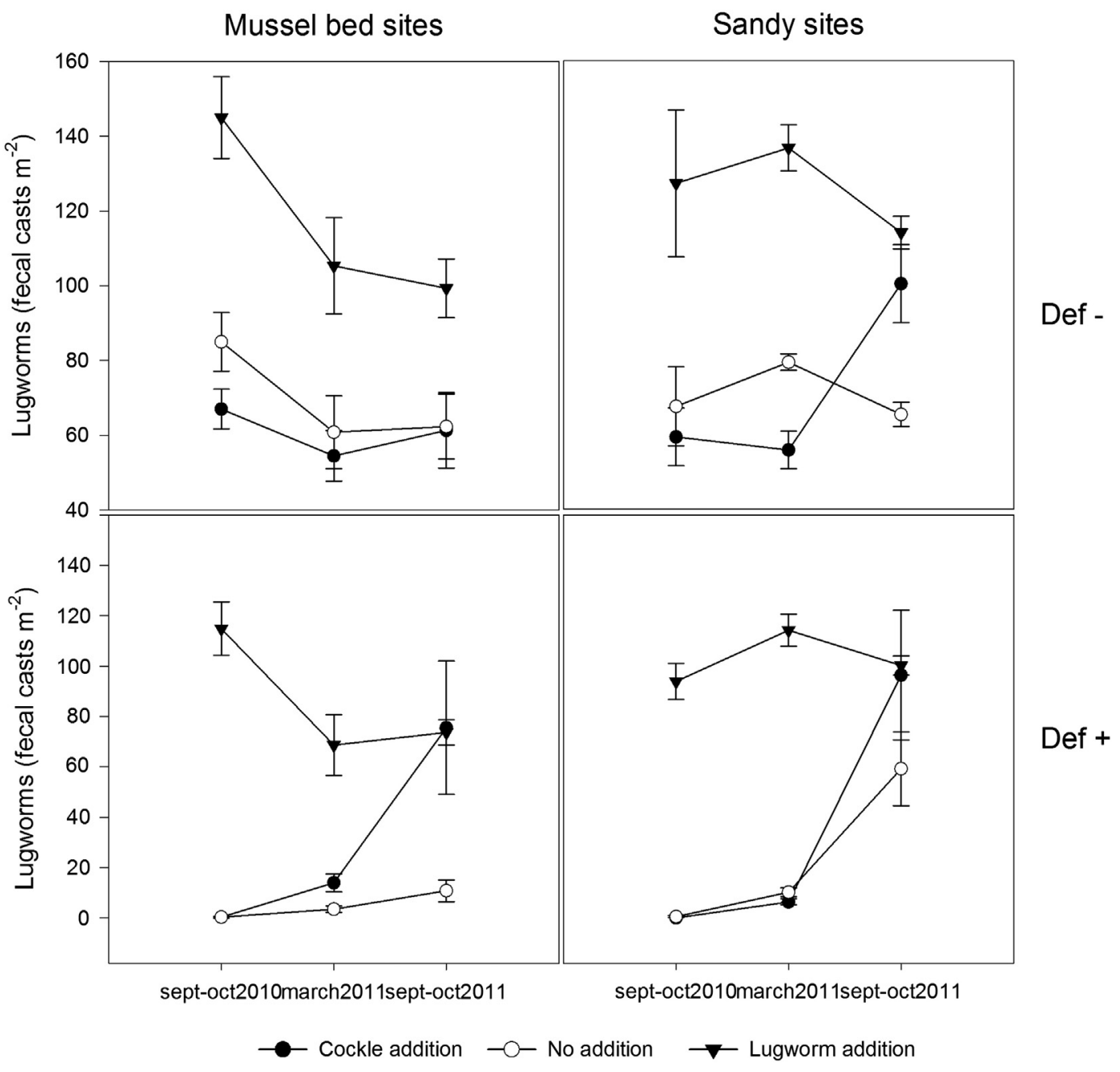

Fig. 3. Total abundances of lugworms in the experimental plots over one year.

Utrecht, The Netherlands), dried, weighed and placed in the center of each plot so that the bottom of the cylinders was flush with the sediment surface. After four tidal cycles (about $46 \mathrm{~h}$ ), plaster cylinders were retrieved and dried until constant weight. Laboratory experiments showed that the dissolution rate of plaster is a good (relative) measurement of water flow speed (Thompson and Glenn, 1994). However, under field conditions the loss of plaster will also indicate the magnitude of the abrasion effect by sediment suspended in the water column, and is therefore a general proxy for the erosive power of the currents.

The influence of hydrodynamic forces was investigated in May 2012 in a nearby intertidal area $\left(53^{\circ} 28^{\prime} 5.92^{\prime \prime} \mathrm{N}, 6^{\circ} 13^{\prime} 47.39^{\prime \prime} \mathrm{E}\right)$ at the same tidal elevation as the experimental site but far away from any bivalve reefs, in order to disentangle effects of mussel beds and water currents on the abundance of juvenile cockles. Here, plaster dissolution (see above) and numbers of juvenile cockles (within a $0.5 \times 0.5 \mathrm{~m}$ frame) were estimated at twenty-one stations along three $500 \mathrm{~m}$ long transects perpendicular to the shore.

\subsection{Data analysis}

Effects of cockles and lugworms on juvenile cockle abundance (averages across all sampling dates) were explored by a generalized linear mixed-model including the fixed factors Engineer addition (three levels: cockle addition, lugworm addition, no addition), Habitat (two levels: sandy sites, mussel bed sites), Defaunation (two levels: defaunated, not defaunated) and their interactions, and a random factor block (eight levels) nested within site (four levels). A negative binomial error distribution with log-link function was selected among other distributions based on the lowest Akaike Information Criterion (AIC) value. A linear mixed-model including the same fixed and random factors listed above was used to explore treatment effects on plaster weight loss, bed level height, sediment organic matter and silt content percentages (averages across all sampling dates). For all response variables, addition of the random effects improved significantly the model fit, as indicated by AIC values and Likelihood Ratio tests, after $p$ values were corrected for testing on the boundary (Zuur et al., 2009). To account for heteroscedasticity, different residual variance structures were included in each model (Zuur et al., 2009). Comparisons based on AIC values revealed that the best models were those where the variance was allowed to differ between either blocks or habitats. Significant treatment effects were assessed through a stepwise backward elimination method, where nested models were compared through a Likelihood Ratio test (Diggle et al., 2002). Independence, normality and homogeneity of variance of residuals were confirmed by plotting relationships between residuals vs random factors and fitted values, and observed vs theoretical quantiles (QQ-plots), respectively. Where appropriate, multiple comparisons were performed and the familywise error rate was controlled with the Bonferroni correction.

To explore the effect of hydrodynamic forces on juvenile cockles, correlations between densities of juvenile cockles and plaster weight loss measured in the experimental plots (averages of all treatment combinations considered) and along transects (all replicates considered) were calculated using Spearman's rank correlation coefficient. All statistical calculations were carried out in R (CRAN, 2010). 


\section{Results}

\subsection{Juvenile cockles and sediment conditions}

Our experiment demonstrates that both the addition of cockles and the vicinity of mussel reefs enhanced the abundances of juvenile cockles (Fig. 4A). The numbers of juvenile cockles in cockle-addition plots were on average 2 and 1.5 fold higher than in no-addition plots and lugwormaddition plots, respectively (main effect of Engineer addition: Chisquared test statistic $=24.07, p<0.001$; post-hoc test, $p<0.001$ for both comparisons). Coastward of the mussel bed juvenile cockles were between 4 and 5 times more abundant than at the sandy sites but abundances decreased overall in defaunated plots, despite higher values in both cockle and lugworm-addition plots compared to noaddition plots (interaction effect between Habitat and Defaunation: Chi-squared test statistic $=5.83, p=0.016$ ).

Bed level measurements showed that cockles enhanced sediment accretion, and this effect was stronger at the sandy sites than at the mussel bed sites (interaction effect between Engineer addition and Habitat: Likelihood Ratio test statistic $=6.78, p=0.034$; Figs. $4 \mathrm{~B}$ and $5)$. Bed level in the cockle-addition plots raised by on average $2.10 \pm$ $0.91 \mathrm{~cm}$ (mean $\pm \mathrm{SD} ; n=16$ ) over the summer (March-September 2011) at the sandy site, while no-addition plots and lugwormaddition plots raised only by on average $0.50 \pm 0.60 \mathrm{~cm}$ (mean $\pm S D$;

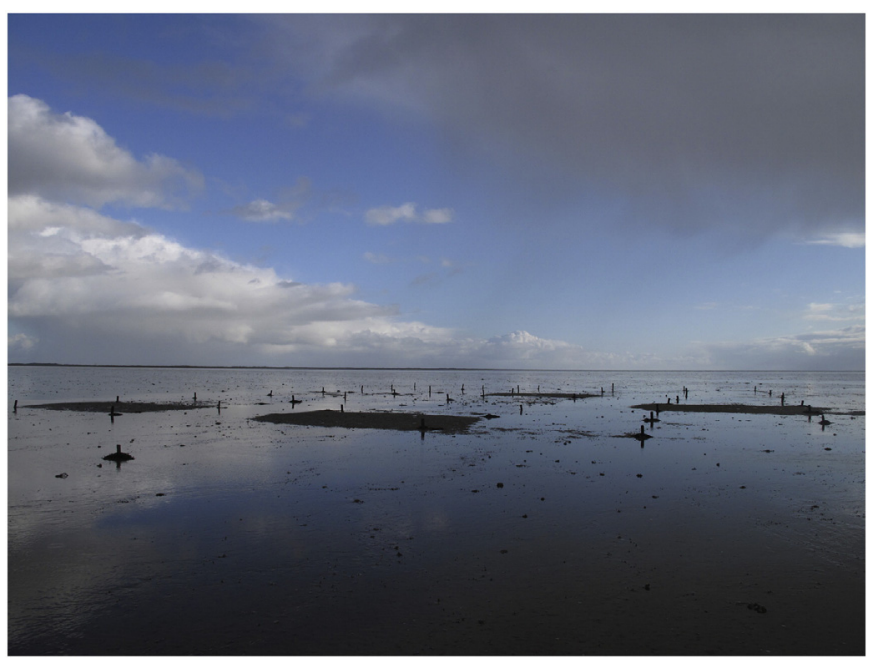

Fig. 5. Photograph showing one block of twelve $5 \times 5 \mathrm{~m}$ experimental plots at one of the sandy sites. Cockle-addition plots appear as dark squares, as they are more elevated and therefore dry off sooner than the other plots and the surrounding.
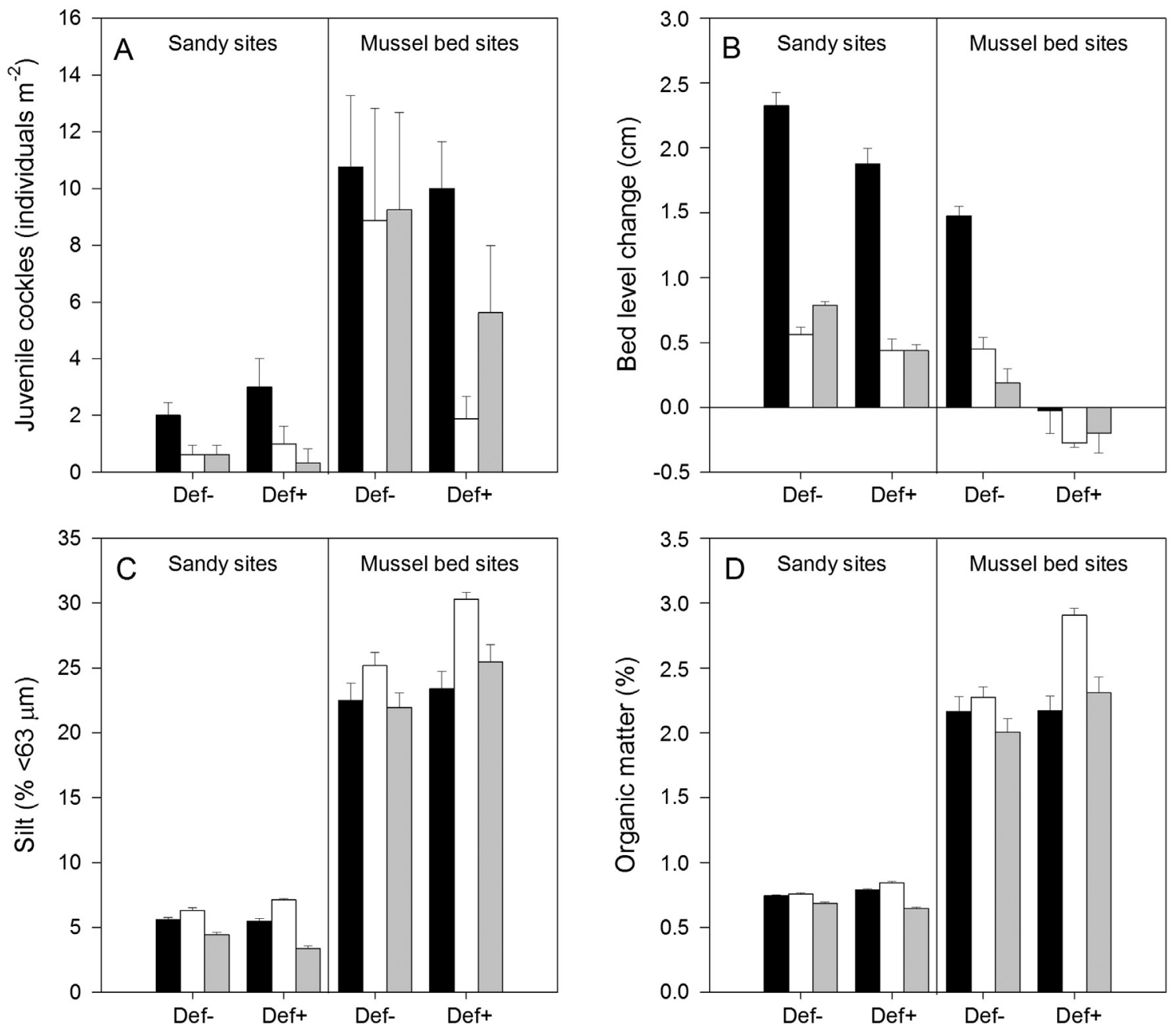

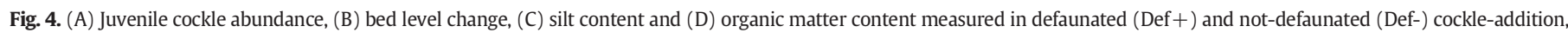
lugworm-addition and no-addition plots at sandy sites and mussel bed sites. Mean $\pm \operatorname{SE}(n=8)$. 
$n=16$ ) and $0.61 \pm 0.35 \mathrm{~cm}$ (mean $\pm \mathrm{SD} ; n=16$ ), respectively. Defaunation reduced sediment accumulation by $61 \%$ overall (main effect of Defaunation: Likelihood Ratio test statistic $=26.73, p<0.001$ ). The effects of defaunation were particularly clear at the mussel bed sites, where reduction of macrofauna resulted in a trend towards sediment erosion in both the no-addition and addition plots (Fig. 4B).

Engineering of cockles and lugworms generally resulted in a decrease of silt and organic matter content in the sediment. Coastward of mussel reefs, where silt and organic content were respectively more than 3 and 2 times higher than at the sandy sites, defaunation led to further enhancement of silt content (interaction effect between Defaunation and Habitat: Likelihood Ratio test statistic $=9.36, p=0.002$; Fig. 4C) and organic matter content, which was significantly attenuated by both cockle and lugworm additions (interaction effect between Defaunation, Habitat and Engineer addition: Likelihood Ratio test statistic $=7.58, p=0.023$; Fig. 4D). At the sandy sites, the bioturbating activity of lugworms significantly reduced silt content (interaction effect between Habitat and Engineer addition: Likelihood Ratio test statistic $=7.68, p=0.022$; Fig. 4C) and organic matter content compared to the other treatments, although for the latter this effect was significant only in defaunated plots (interaction effect between Habitat, Engineer addition and Defaunation: Likelihood Ratio test statistic $=7.58, p=0.023$; Fig. 4D).

\subsection{Hydrodynamic conditions and field surveys}

Slower water currents and reduced scouring from bedload transport were indicated by an overall $8 \%$ decrease in average plaster loss at the mussel bed sites compared to the sandy sites (main effect of Habitat: Likelihood Ratio test statistic $=5.02, p=0.025$ ), and were corroborated by other studies performed in the same area (Donadi et al., 2013a,b). We found no evidence of experimental treatment effects on plaster dissolution in any of the sites.

Field transects data collected in a nearby tidal flat showed a negative relationship between juvenile cockle abundances and the erosive power of waves and currents $\left(r_{s}=-0.71, n=21, p<0.001\right.$; Fig. 6A). A similar negative relationship between numbers of juvenile cockles and plaster weight loss was mirrored in the averages from the experimental treatment combinations $\left(r_{s}=-0.68, n=12, p=0.014\right.$; Fig. 6B). However, in defaunated plots coastward of the mussel beds where neither cockles nor lugworms were added, abundances of juvenile cockles were still very low despite the reduced plaster dissolution (Figs. 6B, 7).

\section{Discussion}

Our results show that positive feedbacks between cockles and habitat characteristics can be important for the survival of cockle populations on the tidal flats of the Wadden Sea. In our study the amount of juvenile cockles was enhanced in the presence of high densities of adults, likely due to the ability of adult cockles to increase sediment stability. Hence, our findings support the notion that non-linear dynamics in soft-bottom intertidal systems may have important implications for both the stability and management of bivalve populations.

To date, many shellfish populations worldwide have shown limited recovery following human overfishing (Jackson et al., 2001; Lotze et al., 2006). With our work we suggest that the lack of recovery of overexploited shellfish populations could at least in part be explained by the loss of positive feedbacks between engineering species and habitat changes. Many bivalve species show evidence of positive feedbacks mediated by habitat amelioration (Gutiérrez et al., 2003). Aggregations of shell-producing organisms can provide protection from predation (Dolmer, 1998; Peterson and Black, 1993) or physical disturbance (Stiven and Gardner, 1992), thus reducing mortality rates of conspecifics. Mussel reefs create substrata that facilitate the attachment and survival of mussel larvae (Bertness and Grosholz, 1985; van der Heide et al., 2014), and alleviate hydrodynamic stress, possibly enhancing recruitment of cockles (Donadi et al., 2013a, this study). A recent study on
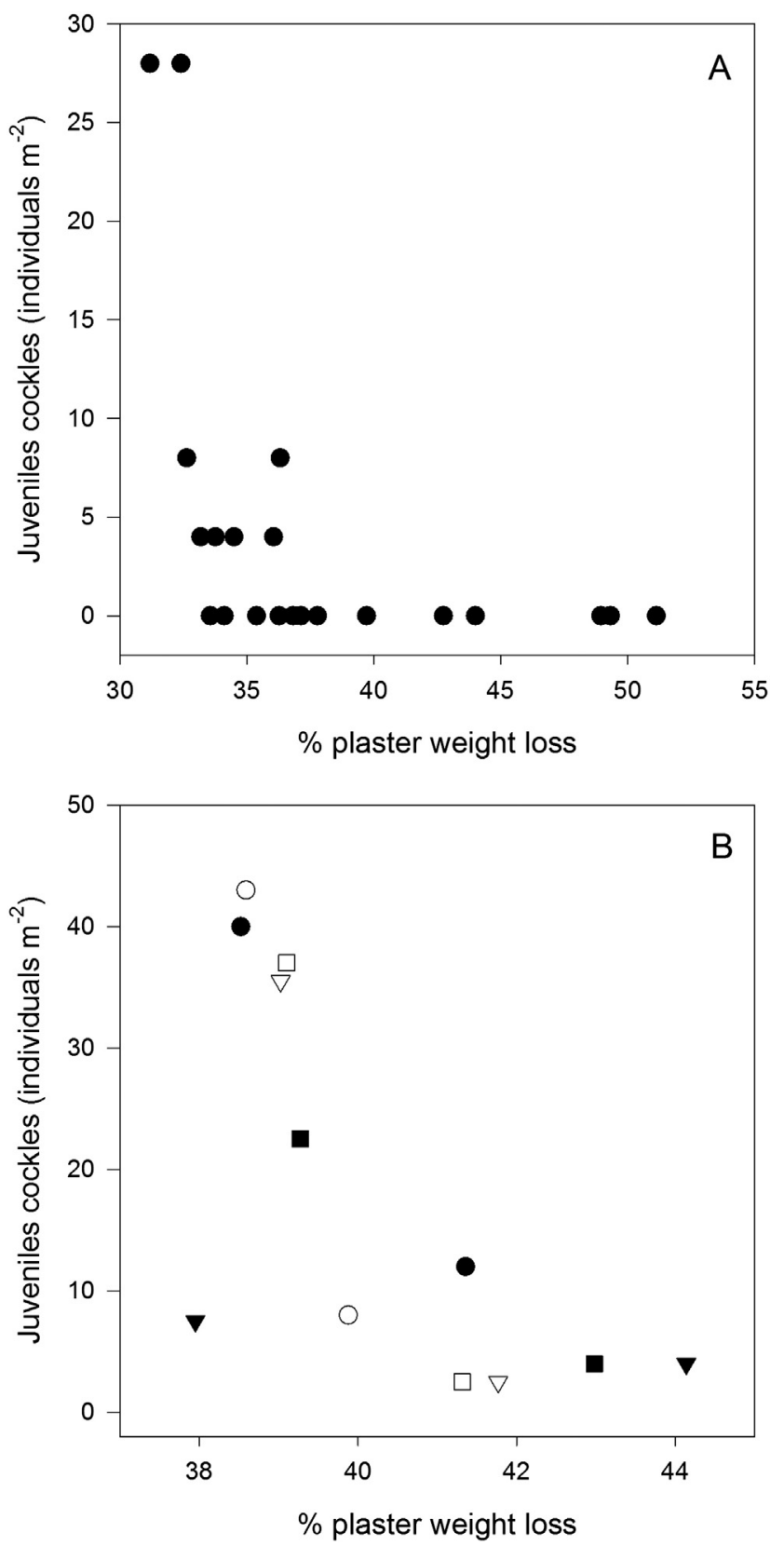

Fig. 6. (A) Scatter plot of juvenile cockle abundance and plaster weight loss measured along three transects perpendicular to the shore in a tidal flat with no mussel reefs $(\mathrm{n}=21)$. (B) Scatter plot of means of juvenile cockle abundances and plaster weight loss $(\mathrm{n}=8)$ measured in defaunated (black) and not-defaunated (white) cockle-addition (circles), lugworm-addition (squares) and no-addition plots (triangles).

oyster restoration showed that spat densities correlated positively with the density of adult oysters (Schulte et al., 2009) that facilitate spat settlement and provide refuge from predation (O'Beirn et al., 2000). These studies demonstrate that several bivalve species are co-operative ecosystem engineers, as their ability to thrive depends on the habitat modification promoted by many individuals. Therefore, there might be density thresholds below which recovery of shellfish populations is not possible. While evidence of positive feedbacks mediated by engineering exists for epibenthic and reef-forming bivalves, our results suggest that similar mechanisms are essential for the persistence and recovery of infaunal bivalves as well. The existence of such non-linear dynamics entails that depletion of bivalve stocks below the level necessary for habitat amelioration may result in further declines and slow recovery rates of target populations. 


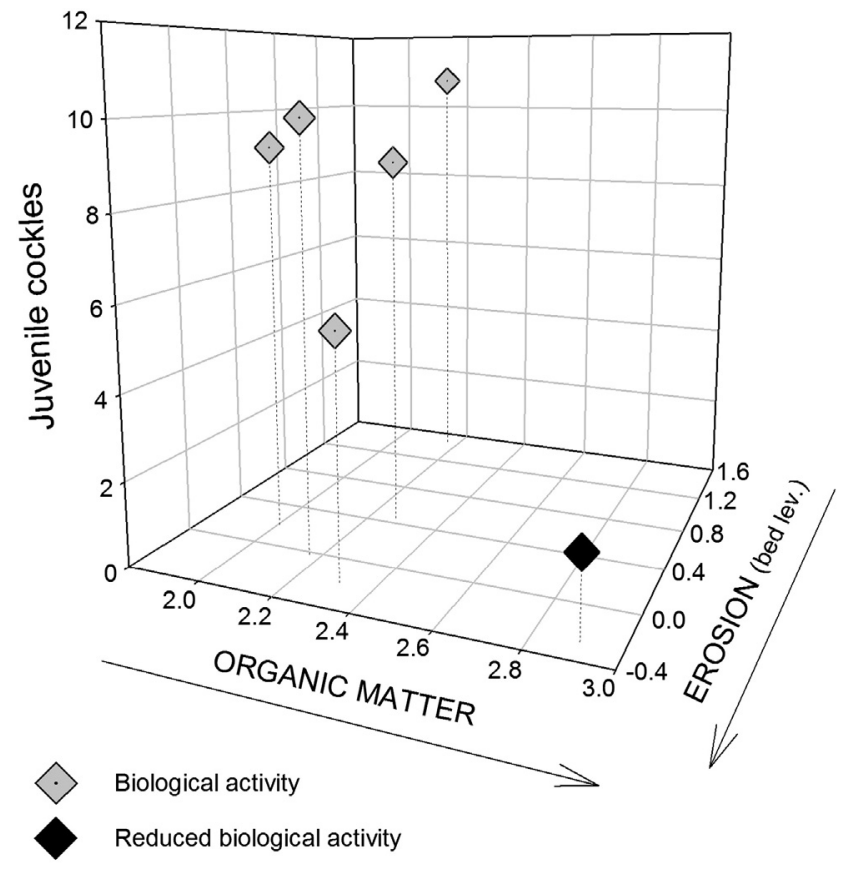

Fig. 7. Scatter plot showing how reduced biological activity in the defaunated no-addition plots (black) results in high stress along two environmental gradients and reduced juvenile cockle abundances compared to the other treatments (gray). Values are averages of organic matter content (\%), bed level change $(\mathrm{cm})$ and cockle juvenile abundance (individuals $\mathrm{m}^{-2}$ ) from different treatments at the mussel bed sites.

At our sites, we found that juvenile cockle densities were enhanced through facilitation by adult conspecifics. This is in contrast with previous evidence of negative effects of adult cockles on cockle larvae due to ingestion (e.g. André and Rosenberg, 1991; Flach, 1996). Indeed, among the variety of interactions demonstrated between adults and juveniles in soft-bottom communities (e.g. Olafsson et al., 1994; Thrush et al., 1996; Woodin, 1991), density-dependent inhibition of recruits by adults has been frequently shown by both manipulative and monitoring studies (e.g. Thrush et al., 1997; Turner et al., 1997). These apparent inconsistencies could result from differential interactions between local environmental conditions (i.e. hydrodynamic conditions) and biotic processes (e.g. Thrush et al., 1996, 2000; Wright et al., 2006). However, the lower experimental densities and smaller spatial scales considered in previous studies, as well as landscape factors such as site connectivity and habitat fragmentation, could also be the cause (Hewitt and Cummings, 2013; Hewitt et al., 1997), as both the densities and the spatial and temporal extent of ecosystem engineers affect the magnitude of habitat modification (Cuddington et al., 2009; Jones et al., 1997), and the patchiness of bivalve populations may influence local availability of recruits. In our study, thirty-two $25 \mathrm{~m}^{-2}$ cockle-dominated communities were created and monitored over one year, offering an unprecedented opportunity to investigate engineering effects of adult cockles on recruitment success of juveniles, defined here as the result of settlement and survival of 3 to 6 month individuals. Yet, although larger than in previous studies, the spatial extent of our artificial populations is much smaller than naturally occurring cockle beds, which can extend for hundreds of meters (Jensen, 1992, pers. obs.).

Our study suggests that cockles promote future generations by increasing sediment stability. Recruitment on tidal flats can be strongly limited by water current velocities and sediment resuspension (Abelson and Denny, 1997; Bouma et al., 2001; Jonsson et al., 2004). At sandy sites characterized by rough hydrodynamic conditions, high densities of cockles promoted an average increase in bed level of $2 \mathrm{~cm}$ in twelve plots of $25 \mathrm{~m}^{-2}$ during summer time. Sediment stabilization by cockles was previously documented in the experimental plots (Donadi et al., 2013b) and could be due to the joined effect of functional and structural traits of cockles (i.e. production of mucus-rich biodeposits and protruding shells from the substrate). However, alternative mechanisms explaining the observed positive adult-juvenile interactions, such as the release of detectable chemical cues from conspecifics (e.g. Butman et al., 1988; Woodin, 1991) or adult cocklemediated lowered predation of juveniles after settlement cannot be dismissed. Also, our experiments were not able to distinguish between settlement and post-settlement survival, and further studies are needed to investigate the relative importance of settlement and postsettlement processes in explaining the observed patterns and corroborate the mechanisms involved.

The higher juvenile cockle densities observed at the mussel bed sites are in agreement with previous evidence of enhanced cockle recruitment and settlement of macrozoobenthos larvae due to declining hydrodynamic energy coastward of mussel reefs (Commito et al., 2005; Donadi et al., 2013a; Widdows and Brinsley, 2002). However, in defaunated plots coastward of mussel reefs, sediment erosion occurred in all treatments, likely impairing cockle recruitment. This is surprising, as defaunation of soft bottoms often results in an increase of diatoms (Van Colen et al., 2010; Volkenborn et al., 2007) that typically enhance sediment stability through the formation of sediment-binding colonies at the surface sediment (van de Koppel et al., 2001). However, the high water content observed in the mussel bed sites even during low tide (pers. obs.) might have hampered sediment stabilization by the water-soluble extracellular polymeric substances (EPS) excreted by diatoms (Blanchard et al., 2000; Weerman et al., 2010). Besides higher sediment instability, defaunated plots at the mussel bed sites where neither cockles nor lugworms had been added experienced a strong increase of organic matter and silt content. Decomposition of mussel biodeposits can increase sediment oxygen consumption, leading to anoxia and accumulation of sulfides in the pore-water (Christensen et al., 2003; Dahlbäck and Gunnarsson, 1981). This in turn may negatively affect many benthic species (Callier et al., 2009; Hyland et al., 2005) in a way similar to the observed defaunation impact in our experiment (Fig. 7). Overall, our results suggest that cockles facilitated young generations by increasing sediment stability at the sandy sites and by alleviating the effects of organic enrichment at the mussel bed sites, thus acting as both sediment stabilizators (Andersen et al., 2010; Donadi et al., 2013b) and bioturbators (Flach, 1996; Montserrat et al., 2009; Neumeier et al., 2006).

Contrary to our hypothesis, we did not observe a negative effect of lugworms on juvenile cockles, but rather a positive effect in defaunated plots coastward of mussel reefs. Lugworms are well-known bioturbators (Volkenborn et al., 2007), and accordingly, we found reduced sediment organic matter and silt content in lugworm-addition plots. However, in the sandy sites, effects of lugworm bioturbation on juvenile cockles may have been overwhelmed by effects of water currents and scouring from bedload transport. In the mussel bed sites, the bioturbating activity of lugworms might have facilitated juvenile cockles due to alleviation of anoxic stress (Banta et al., 1999; Norkko et al., 2012). Therefore, effects of lugworms on juvenile cockles are likely conditional on local habitat conditions, such as sediment properties and water currents.

Our results imply that human activities that modify sediment conditions on large scales may impair the recovery of cockles and other shellfish species. Removal of dead shells and live bivalves by mechanical shellfish dredging has been suggested to reduce the substrate available for settlement of blue mussels (Hiddink, 2003). Similarly, the loss of fine silt after dredging events may reduce the bivalve settlement, potentially causing long-term declines of cockle ( $C$. edule) and Balthic tellin (Macoma balthica) stocks in the Wadden Sea (Piersma et al., 2001). With our work, we bring experimental evidence that sediment stabilization may be an important factor for recruitment success of cockles. We argue that overexploitation of bivalve stocks combined with changes in sediment properties in the Wadden Sea (Lotze et al., 2005; Reise, 2005) may at least in part explain observed long-term declines of 
shellfish populations (Eriksson et al., 2010; Kraan et al., 2010). Therefore, conservation and restoration of habitat modifying bivalve species should focus on protecting existing populations, reducing (anthropogenic) disturbances, and restoring or preserving habitat conditions that nourish ecological feedbacks.

\section{Acknowledgments}

We thank Vereniging Natuurmonumenten for granting us permission for the field work on the tidal flats. We thank Judith Westveer, Jeroen Kuypers, Tim Ruiter, Jim de Fouw, Karin de Boer, Stefania Gemignani, Nicola Stefani, Maarten Schrama, Pieter Heijning, Katrin Reiss, Linda Franken and Guus Diepenmaat for the help in the field, and Johan Eklöf for the advice on the experimental design. We are grateful to all reviewers for helpful comments on earlier drafts of this manuscript. This study was financed by a grant from the ZKO program of the Netherlands Organization of Scientific Research (NWO) to BKE (grant no. 839.08.310). [ST]

\section{References}

Abelson, A., Denny, M., 1997. Settlement of marine organisms in flow. Annu. Rev. Ecol. Syst. 28, 317-339

Airoldi, L., Beck, M.W., 2007. Loss, status and trends for coastal marine habitats of Europe. In: Gibson, R.N., Atkinson, R.J. Gordon, J.D.M. (Eds.), Oceanography and Marine Biology: An Annual Reviewvol. 45. CRC Press, pp. 345-405

Andersen, T.J.,Lanuru, M.,van Bernem, C.,Pejrup, M., Riethmueller, R., 2010. Erodibility of a mixed mudflat dominated by microphytobenthos and Cerastoderma edule, East Frisian Wadden Sea, Germany. Estuar. Coast. Shelf Sci. 87, 197-206.

André, C., Rosenberg, R., 1991. Adult-larval interactions in the suspension-feeding bivalves Cerastoderma edule and Mya arenaria. Mar. Ecol. Prog. Ser. 71, 227-234.

Armonies, W., 1996. Changes in distribution patterns of 0-group bivalves in the Wadden Sea: byssus-drifting releases juveniles from the constraints of hydrography. J. Sea Res. 35, 323-334.

Armonies, W.,Hellwig-Armonies, M., 1992. Passive settlement of Macoma balthica spat on tidal flats of the Wadden Sea and subsequent migration of juveniles. Neth. J. Sea Res. 29, 371-378.

Arnold, W.S., Blake, N.J., Harrison, M.M., Marelli, D.C., Parker, M.L., Peters, S.C., Sweat, D.E 2005. Restoration of bay scallop (Argopecten irradians (Lamarck)) populations in Florida coastal waters: planting techniques and the growth, mortality and reproductive development of planted scallops. J. Shellfish Res. 24, 883-904.

Banta, G.,Holmer, M.,Jensen, M., Kristensen, E., 1999. Effects of two polychaete worms, Nereis diversicolor and Arenicola marina, on aerobic and anaerobic decomposition in a sandy marine sediment. Aquat. Microb. Ecol. 19, 189-204.

Bertness, M.D., Grosholz, E., 1985. Population dynamics of the ribbed mussel, Geukensia demissa: the costs and benefits of an aggregated distribution. Oecologia 67, 192-204.

Bertness, M.D., Leonard, G.H., 1997. The role of positive interactions in communities: lessons from intertidal habitats. Ecology 78, 1976-1989.

Beukema, J.J., Devlas, J., 1979. Population parameters of the lugworm, Arenicola marina living on tidal flats in the Dutch Wadden Sea. Neth. J. Sea Res. 13, 331-353.

Blanchard, G.F.,Paterson, D.M.,Stal, L.J., Richard, P., Galois, R., Huet, V., Kelly, J., Honeywill, C., de Brouwer, J., Dyer, K.,Christie, M.,Seguignes, M., 2000. The effect of geomorphological structures on potential biostabilisation by microphytobenthos on intertidal mudflats. Cont. Shelf Res. 20, 1243-1256.

Boogert, N.J.,Paterson, D.M.,Laland, K.N., 2006. The implications of niche construction and ecosystem engineering for conservation biology. Bioscience 56, 570-578.

Bouma, H., Duiker, J.M.C., de Vries, P.P.,Herman, P.M.J.,Wolff, W.J., 2001. Spatial pattern of early recruitment of Macoma balthica (L.) and Cerastoderma edule (L.) in relation to sediment dynamics on a highly dynamic intertidal sandflat. J. Sea Res. 45, 79-93.

Brey, T., 1989. Der Einfluss physikalischer und biologischer Faktoren auf Struktur und Dynamik der sublitoralen Macoma. Gemeinschaft Kiel. Bucht 186, 123-175.

Butman, C.A.,Grassle, J.P.,Webb, C.M., 1988. Substrate choices made by marine larvae settling in still water and in a flume flow. Nature 333, 771-773.

Byers, J.E., Cuddington, K., Jones, C.G., Talley, T.S., Hastings, A., Lambrinos, J.G., Crooks, J.A., Wilson, W.G., 2006. Using ecosystem engineers to restore ecological systems. Trends Ecol. Evol. 21, 493-500.

Callier, M.D.,Richard, M.,McKindsey, C.W.,Archambault, P.,Desrosiers, G., 2009. Responses of benthic macrofauna and biogeochemical fluxes to various levels of mussel biodeposition: an in situ "benthocosm" experiment. Mar. Pollut. Bull. 58, 1544-1553.

Christensen, P.B., Glud, R.N., Dalsgaard, T., Gillespie, P., 2003. Impacts of longline musse farming on oxygen and nitrogen dynamics and biological communities of coastal sediments. Aquaculture 218, 567-588.

Ciutat, A., Widdows, J., Pope, N.D., 2007. Effect of Cerastoderma edule density on near-bed hydrodynamics and stability of cohesive muddy sediments. J. Exp. Mar. Biol. Ecol. 346, 114-126.

Commito, J.A., Celano, E.A., Celico, H.J., Como, S., Johnson, C.P., 2005. Mussels matter: postlarval dispersal dynamics altered by a spatially complex ecosystem engineer. J. Exp. Mar. Biol. Ecol. 316, 133-147.
CRAN, 2010. R: A Language and Environment for Statistical Computing. R Foundation for Statistical computing, Vienna, Austria.

Cuddington, K.,Wilson, W.G., Hastings, A., 2009. Ecosystem engineers: feedback and population dynamics. Am. Nat. 173, 488-498.

Dahlbäck, B., Gunnarsson, L., 1981. Sedimentation and sulfate reduction under a mussel culture. Mar. Biol. 63, 269-275.

Diggle, P.J.,Heagerty, P.,Liang, K.Y.,Zeger, S.L., 2002. Analysis of Longitudinal Data, 2nd edition. Oxford University Press.

Dolmer, P., 1998. The interactions between bed structure of Mytilus edulis L. and the predator Asterias rubens L. J. Exp. Mar. Biol. Ecol. 228, 137-150.

Donadi, S., van der Heide, T., van der Zee, E.M., Eklöf, J.S., van de Koppel, J., Weerman, E.J., Piersma, T., Olff, H., Eriksson, B.K., 2013a. Cross-habitat interactions among bivalve species control community structure on intertidal flats. Ecology 94, 489-498.

Donadi, S., Westra, J., Weerman, E.J., van der Heide, T., van der Zee, E.M., Koppel, J., Olff, H., Piersma, T.,van der Veer, H.W.,Eriksson, B.K., 2013b. Non-trophic interactions control benthic producers on intertidal flats. Ecosystems 16, 1325-1335.

Eriksson, B.K., van der Heide, T., Koppel, J., Piersma, T., van der Veer, H.W., Olff, H., 2010. Major changes in the ecology of the Wadden Sea: human impacts, ecosystem engineering and sediment dynamics. Ecosystems 13, 752-764.

Flach, E.C., 1992. Disturbance of benthic infauna by sediment-reworking activities of the lugworm Arenicola marina. Neth. J. Sea Res. 30, 81-89.

Flach, E.C., 1996. The influence of the cockle, Cerastoderma edule, on the macrozoobenthic community of tidal flats in the Wadden Sea. Mar. Ecol. 17, 87-98.

Flach, E.C., Beukema, J.J., 1994. Density-governing mechanisms in populations of the lugworm Arenicola marina on tidal flats. Mar. Ecol. Prog. Ser. 115, 139-149.

Gurney, W.S.C., Lawton, J.H., 1996. The population dynamics of ecosystem engineers, Oikos 76, 273-283.

Gutiérrez, J., Jones, C., Strayer, D., Iribarne, O., 2003. Mollusks as ecosystem engineers: the role of shell production in aquatic habitats. Oikos 101, 79-90.

Hewitt, J., Cummings, V., 2013. Context-dependent success of restoration of a key species, biodiversity and community composition. Mar. Ecol. Prog. Ser. 479, 63-73.

Hewitt, J.E., Legendre, P., McArdle, B.H., Thrush, S.F., Bellehumeur, C., Lawrie, S.M., 1997. Identifying relationships between adult and juvenile bivalves at different spatial scales. J. Exp. Mar. Biol. Ecol. 216, 77-98.

Hiddink, J.G., 2003. Effects of suction-dredging for cockles on non-target fauna in the Wadden Sea. J. Sea Res. 50, 315-323.

Hui, C., Li, Z.,Yue, D., 2004. Metapopulation dynamics and distribution, and environmental heterogeneity induced by niche construction. Ecol. Model. 177, 107-118.

Hyland, J.,Balthis, L.,Karakassis, I.,Magni, P.,Petrov, A.,Shine, J.,Vestergaard, O.,Warwick, R., 2005. Organic carbon content of sediments as an indicator of stress in the marine benthos. Mar. Ecol. Prog. Ser. 295, 91-103.

Jackson, J.B., Kirby, M.X., Berger, W.H., Bjorndal, K.A., Botsford, L.W., Bourque, B.J., Bradbury, R.H., Cooke, R., Erlandson, J., Estes, J.A., Estes, J.A., Hughes, T.P., Kidwell, S., Lange, C.B., Lenihan, H.S., Pandolfi, J.M., Peterson, C.H., Steneck, R.S., Tegner, M.J., Warner, R.R., 2001. Historical overfishing and the recent collapse of coastal ecosystems. Science 293, 629-638.

Jensen, K.T., 1992. Dynamics and growth of the cockle, Cerastoderma edule, on an intertidal mud-flat in the Danish Wadden sea: effects of submersion time and density. Neth. J. Sea Res. 28, 335-345.

Jones, C.G., Lawton, J.H., Shachak, M., 1994. Organisms as ecosystem engineers. Oikos 69, 373-386.

Jones, C.G., Lawton, J.H., Shachak, M., 1997. Positive and negative effects of organisms as physical ecosystem engineers. Ecology 78, 1946-1957.

Jonsson, P.R., Berntsson, K.M., Larsson, A.I., 2004. Linking larval supply to recruitment: flow-mediated control of initial adhesion of barnacle larvae. Ecology 85, 2850-2859.

Kater, B.J., Geurts van Kessel, A.J.M., Baars, J.J.M.D., 2006. Distribution of cockles Cerastoderma edule in the Eastern Scheldt: habitat mapping with abiotic variables. Mar. Ecol. Prog. Ser. 318, 221-227.

Kirby, M.X., 2004. Fishing down the coast: historical expansion and collapse of oyster fisheries along continental margins. Proc. Natl. Acad. Sci. U. S. A. 101, 13096-13099.

Kraan, C., Aarts, G.,Van Der Meer, J.,Piersma, T., 2010. The role of environmental variables in structuring landscape-scale species distributions in seafloor habitats. Ecology 91, $1583-1590$.

Laland, K.N., Odling-Smee, F.J.,Feldman, M.W., 1999. Evolutionary consequences of niche construction and their implications for ecology. Proc. Natl. Acad. Sci. U. S. A. 96, 10242-10247.

Lenihan, H.S., Peterson, C.H., 1998. How habitat degradation through fishery disturbance enhances impacts of hypoxia on oyster reefs. Ecol. Appl. 8, 128-140.

Lotze, H.K., 2005. Radical changes in the Wadden Sea fauna and flora over the last 2,000 years. Helgol. Mar. Res. 59, 71-83.

Lotze, H.K., Reise, K., Worm, B., van Beusekom, J., Busch, M., Ehlers, A., Heinrich, D. Hoffmann, R.C., Holm, P., Jensen, C., Knottnerus, O.S., Langhanki, N., Prummel, W., Vollmer, M.,Wolff, W.J., 2005. Human transformations of the Wadden Sea ecosystem through time: a synthesis. Helgol. Mar. Res. 59, 84-95.

Lotze, H.K., Lenihan, H.S., Bourque, B.J., Bradbury, R.H., Cooke, R.G., Kay, M.C., Kidwell, S.M., Kirby, M.X., Peterson, C.H., Jackson, J.B.C., 2006. Depletion, degradation, and recovery potential of estuaries and coastal seas. Science 312, 1806-1809.

Marsden, I.D.,Adkins, S.C., 2009. Current status of cockle bed restoration in New Zealand. Aquac. Int. 18, 83-97.

May, R.M., 1977. Thresholds and breakpoints in ecosystems with a multiplicity of stable states. Nature 269, 471-477.

Medina, B.,Guzman, H.M.,Mair, J.M., 2007. Failed recovery of a collapsed scallop Argopecten ventricosus fishery in Las Perlas Archipelago, Panama. J. Shellfish Res. 26, 9-15.

Montserrat, F., Van Colen, C., Provoost, P., Milla, M., Ponti, M., Van den Meersche, K., Ysebaert, T.,Herman, P.M.J., 2009. Sediment segregation by biodiffusing bivalves. Estuar. Coast. Shelf Sci. 83, 379-391. 
Neumeier, U.,Lucas, C.H.,Collins, M., 2006. Erodibility and erosion patterns of mudflat sediments investigated using an annular flume. Aquat. Ecol. 40, 543-554.

Norkko, J.,Reed, D.C.,Timmermann, K.,Norkko, A.,Gustafsson, B.G.,Bonsdorff, E.,Slomp, C.P. Carstensen, J.,Conley, D.J., 2012. A welcome can of worms? Hypoxia mitigation by an invasive species. Glob. Chang. Biol. 18, 422-434.

Nyström, M., Norström, A.V., Blenckner, T., la Torre-Castro, M., Eklöf, J.S., Folke, C., Österblom, H.,Steneck, R.S., Thyresson, M., Troell, M., 2012. Confronting feedbacks of degraded marine ecosystems. Ecosystems 15, 695-710.

O'Beirn, F.X.,Luckenbach, M.W.,Nestlerode, J.A., Coates, G.M., 2000. Toward design criteria in constructed oyster reefs: oyster recruitment as a function of substrate type and tidal height. J. Shellfish Res. 19, 387-395.

Olafsson, E.B., Peterson, C.H., Ambrose, W.G., 1994. Does recruitment limitation structure populations and communities of macroinvertebrates in marine soft sediments the relative significance of presettlement and postsettlements processes. Oceanogr. Mar. Biol. 65-109.

Peterson, C., Black, R., 1993. Experimental tests of the advantages and disadvantages of high density for two coexisting cockles in a Southern Ocean lagoon. J. Anim. Ecol. 62, 614-633.

Piersma, T., Koolhaas, A., Dekinga, A., Beukema, J.J., Dekker, R., Essink, K., 2001. Long-term indirect effects of mechanical cockle-dredging on intertidal bivalve stocks in the Wadden Sea. J. Appl. Ecol. 38, 976-990.

Reise, K., 2005. Coast of change: habitat loss and transformations in the Wadden Sea. Helgol. Mar. Res. 59, 9-21.

Scheffer, M., Carpenter, S.R., 2003. Catastrophic regime shifts in ecosystems: linking theory to observation. Trends Ecol. Evol. 18, 648-656.

Scheffer, M., Carpenter, S., Foley, J.A., Folke, C., Walker, B., 2001. Catastrophic shifts in ecosystems. Nature 413, 591-596.

Schückel, U., Kröncke, I., 2013. Temporal changes in intertidal macrofauna communities over eight decades: a result of eutrophication and climate change. Estuar. Coast. Shelf Sci. 117, 210-218.

Schulte, D.M., Burke, R.P.,Lipcius, R.N., 2009. Unprecedented restoration of a native oyster metapopulation. Science 325, 1124-1128.

Stiven, A.E., Gardner, S.A., 1992. Population processes in the ribbed mussel Geukensia demissa (Dillwyn) in a North Carolina salt-marsh tidal gradient - spatial pattern, predation, growth and mortality. J. Exp. Mar. Biol. Ecol. 160, 81-102.

Thompson, T.L., Glenn, E.P., 1994. Plaster standards to measure water motion. Limnol. Oceanogr. 39, 1768-1779.

Thrush, S.F.,Hewitt, J.E.,Pridmore, R.D.,Cummings, V.J., 1996. Adult/juvenile interactions of infaunal bivalve: contrasting outcomes in different habitats. 132, 83-92.

Thrush, S., Cummings, V., Dayton, P., Ford, R., Grant, J., Hewitt, J., Hines, A., Lawrie, S. Pridmore, R., Legendre, P., McArdle, B., Schneider, D., Turner, S., Whitlatch, R., Wilkinson, M., 1997. Matching the outcome of small-scale density manipulation experiments with larger scale patterns: an example of bivalve adult/juvenile interactions. J. Exp. Mar. Biol. Ecol. 216, 153-169.

Thrush, S., Hewitt, J., Cummings, V., Green, M., Funnel, G., Wilkinson, M., 2000. The generality of field experiments: interactions between local and broad-scale processes. Ecology $81,399-415$.
Thrush, S.F.,Hewitt, J.E.,Dayton, P.K.,Coco, G., Lohrer, A.M.,Norkko, A., Norkko, J.,Chiantore, M., 2009. Forecasting the limits of resilience: integrating empirical research with theory. Proc. R. Soc. B Biol. Sci. 276, 3209-3217.

Turner, S., Grant, J., Pridmore, R., Hewitt, J., Wilkinson, M., Hume, T., Morrisey, D., 1997. Bedload and water-column transport and colonization processes by post-settlement benthic macrofauna: does infaunal density matter? J. Exp. Mar. Biol. Ecol. 216, 51-75.

Van Colen, C., Montserrat, F., Vincx, M.,Herman, P.M.J.,Ysebaert, T.,Degraer, S., 2010. Longterm divergent tidal flat benthic community recovery following hypoxia-induced mortality. Mar. Pollut. Bull. 60, 178-186.

Van de Koppel, J.,Herman, P.,Thoolen, P.,Heip, C., 2001. Do alternate stable states occur in natural ecosystems? Evidence from a tidal flat. Ecology 82, 3449-3461.

Van der Heide, T.,Tielens, E., van der Zee, E.M.,Weerman, E.J.,Holthuijsen, S., Eriksson, B.K., Piersma, T.,van de Koppel, J., Olff, H., 2014. Predation and habitat modification synergistically interact to control bivalve recruitment on intertidal mudflats. Biol. Conserv. $172,163-169$.

Van der Veer, H.W., Feller, R.J., Weber, A., Witte, I.J.J., 1998. Importance of predation by crustaceans upon bivalve spat in the intertidal zone of the Dutch Wadden Sea as revealed by immunological assays of gut contents. J. Exp. Mar. Biol. Ecol. 231, 139-157.

Van Gils, J.A.,Piersma, T.,Dekinga, A.,Spaans, B., Kraan, C., 2006. Shellfish dredging pushes a flexible avian top predator out of a marine protected area. PLoS Biol. 4, 2399-2404.

van der Zee, E.M.,van der Heide, T.,Donadi, S.,Eklöf, J.S.,Eriksson, B.K.,Olff, H., van der Veer H.W., Piersma, T., 2012. Spatially extended habitat modification by intertidal reefbuilding bivalves has implications for consumer-resource interactions. Ecosystems $15,664-673$.

Volkenborn, N.,Hedtkamp, S.I.C., van Beusekom, J.E.E., Reise, K., 2007. Effects of bioturbation and bioirrigation by lugworms (Arenicola marina) on physical and chemical sediment properties and implications for intertidal habitat succession. Estuar. Coast. Shelf Sci. 74, 331-343.

Walters, C., Kitchell, J.F., 2001. Cultivation/depensation effects on juvenile survival and recruitment: implications for the theory of fishing. Can. J. Fish. Aquat. Sci. 58, 39-50.

Weerman, E.J., van de Koppel, J., Eppinga, M.B., Montserrat, F., Liu, Q.-X., Herman, P.M.J. 2010. Spatial self-organization on intertidal mudflats through biophysical stress divergence. Am. Nat. 176, E15-E32.

Widdows, J., Brinsley, M., 2002. Impact of biotic and abiotic processes on sediment dy namics and the consequences to the structure and functioning of the intertida zone. J. Sea Res. 48, 143-156.

Woodin, S., 1991. Recruitment of infauna: positive or negative cues? Am. Zool. 31 797-807.

Worm, B., Lotze, H.K., 2000. Nutrient pollution, low trophic level harvesting and cumulative human impact on coastal ecosystems. In: Rangeley, R.W. (Ed.), Rockweed: Science and Management. Huntsman Marine Science Center, St. Andrews, NB, Canada, pp. $40-41$.

Wright, J.P.,Jones, C.G.,Boeken, B.,Shachak, M., 2006. Predictability of ecosystem engineering effects on species richness across environmental variability and spatial scales. J Ecol. 94, 815-824

Zuur, A.F.,Ieno, E.N.,Walker, N.,Saveliev, A.A.,Smith, G.M., 2009. Mixed Effects Models and Extensions in Ecology with R. Springer. 